\title{
Zrod intermedií v díle Roberta Rauschenberga
}

\section{The Birth of Intermedia in the Art of Robert Rauschenberg}

\author{
Jozef Cseres / 114731@mail.muni.cz
}

Department of Musicology, Faculty of Arts, Masaryk University, Brno, CZ

\begin{abstract}
In his paper The Birth of Intermedia in the Art of Robert Rauschenberg author deals with the contribution of Robert Rauschenberg to the history of modern intermedia arts. For a long time the Rauschenberg's installations and stage works were overshadowed by the works of his older fellows and collaborators John Cage and Merce Cunningham in spite of important fact that it was Rauschenberg who inspired some of their radical works and brought new impulses into their collaboration. Analysing the significant combine paintings, installations, and multimedia performances, the author explains the historical background as well as the driving impulses behind the crucial crossovers and inventions that mark Rauschenberg's shift from static media (drawing, painting, print) to the temporal an processual ways of representation (performance, stage design, installation). He considers Rauschenberg for one of the most inventive and versatile intermedia artist of the 1960s with remarkable sense for experimenting.
\end{abstract}

\section{Keywords}

Robert Rauschenberg, painting, installation, sound, intermedia, performance, experiment, representation 
Robert Rauschenberg (1925-2008) patří nepochybně k nejvýznamnějším umělcům 2. poloviny 20. století. Přestože to byl důležitý průkopník moderních intermedií, až donedávna byl vnímán především jako malír. Jeho invenční intermedia z 60. let byla dlouho zastíněna př́inosem některých jeho spolupracovníků (John Cage, Merce Cunningham, David Tudor), ačkoli to byl právě Rauschenberg, kdo v legendárním Cageově „proto-happeningu“ (Theater Piece No. 1) v létě 1952 na Black Mountain College (BMC) účinkoval jako DJ, když přehrával staré desky na ještě starším gramofonu, zatímco Cage četl své přednášky, Tudor hrál na klavír, Cunningham tancoval a Mary C. Richardsová a Charles Olson recitovali svoji poezii. Nad multimediální akcí, rozptýlenou do celého prostoru obdélníkového sálu včetně míst pro diváky, se mysticky vznášela Rauschenbergova bílá plátna, nepřehlédnutelný milník ontologického realismu v umění. $\mathrm{K}$ docenění Rauschenberga jako intermediálního tvưrce dochází teprve v posledních letech. Kurátoři historicky první ucelenější retrospektivy jeho rozsáhlého a hlavně mnohovrstevnatého díla, jež nedávno proběhla v londýnské galerii Tate Modern (1. 12. 2016 - 2. 4. 2017) a newyorském Muzeu moderního umění (21. 5. - 17. 9. 2017), se tuto asymetrii snažili napravit, když představili Rauschenbergovu malbu v rovnováze se stejně důležitými akčními a audiovizuálními díly. Upozornili tak na umělcův přirozený vývoj od malby k instalacím a scénickým intermediím i na jeho opakované návraty k malbě.

Rauschenberg vstoupil do světa výtvarného umění na začátku 50 . let, když v něm dominoval abstraktní expresionismus. Od samého počátku své kariéry testoval hranice malírského média a zkoumal povrch plátna tak, že ho otevřel divákovi - nejenom jeho zraku, ale též dalším smyslům a zejména myšlení. Došlo k tomu na BMC v Ashevillu v Severní Karolíně, kam se v roce 1948, po krátkých studiích na Kansas City Art Institute a pařížské Académie Julian, zapsal spolu s tehdejší př́ítelkyní Susan Weilovou, se kterou se seznámil v Paříži. Na legendární škole, proslavené edukačním liberalismem, sice jako studenti setrvali pouze rok, měli však velké štěstí, protože zrovna v té době tam učili nebo hostovali Josef Albers, Buckminster Fuller, John Cage, Merce Cunningham, Willem de Kooning a další vlivné osobnosti. Rauschenberg studoval kresbu a malbu u Alberse, k nim si přibral textilní výtvarnictví (u Anni Albersové a Trude Guermonprezové), hudební analýzu (u Erwina Brodkyho), a chodil i na hodiny moderního tance k Elizabeth Jennerjahnové a sborového zpěvu k Charlotte Schlesingerové. Oni všichni formovali polymúzickou orientaci mladého umělce, hledajícího vhodné a aktuální způsoby, jak přesvědčivě reprezentovat pohyb a gesta ve statickém vizuálním médiu. Po následném dvouletém pobytu v New Yorku, kde se věnoval zejména grafickým experimentům, se Rauschenberg vrátil na BMC, aby tam pokračoval ve studiích malby, tentokrát u Roberta Motherwelleho, a dále s ní experimentoval. V protikladu k tomu, co ho předtím učil Albers, extrémně zredukoval barevnou škálu, až dospěl k základním barvám (bílé a černé) a legendárním Bílým malbám (White Paintigs; 1951), které velmi oslovily Johna Cagea. Zajímaly ho nejenom reprezentační, ale především materiálové vlastnosti barvy; maloval třeba dehtem, asfaltem, či barvou na stěnu, místo štětce používal váleček, a velkou důležitost začal připisovat formátu plátna.

Rauschenbergův odhodlaný radikalismus nejadekvátněji vystihuje ikonoklastické gesto vymazání, jakého se dopustil v díle Vygumovaná de Kooningova kresba (Erased de Kooning 
Drawing; 1953). Zatímco v o dva roky starší Bilé malbě obnažil malířské médium ve stavu iniciačního zrodu a provokující nicoty, pohrávaje si s reprezentačním nihilismem, šmouhy na (staro)novém díle jsou vlastně stopy po tvořivém aktu, adekvátní tahům tužky a uhlíku na přivlastněné kresbě. Hodnotu heretického aktu zvyšuje fakt, že Rauschenberg o svém záměru de Kooninga předem informoval, a ten mu pro tento účel kresbu poskytl, přestože k ní měl vroucí vztah. Duchampovské reference (L.H.O.O.Q., rembrandtovský readymade) jsou v této souvislosti pochopitelně namístě, avšak dílo je nutné historicky vnímat též v kontextu umělcova koketování s abstraktním expresionismem i subverzních strategií nastupující neo-avantgardy. Vygumovaná de Kooningova kresba tudíž nebyla ani tak negací, jak se Rauschenberg sám později nechal slyšet, byla to spíše oslava jednoduchého nápadu, který venkoncem nebylo až tak jednoduché zrealizovat, jak by se na prvý pohled snad mohlo někomu zdát. ${ }^{1}$ Z roku 1953 pochází i další milník výtvarné dekonstrukce - přes 7 metrů dlouhá nekonvenční malba-tisk, nazvaná autoreferenčně Otisk automobilové pneumatiky (Automobile Tire Print). I tu umělec realizoval gumou, tentokrát s pomocí Johna Cagea, kterého vyzval, aby svým autem značky Ford s nabarvenou pneumatikou přejel přes pás slepených listů kancelářského papíru, čímž zanechal na bílém podkladu rovnou souvislou stopu. ${ }^{2}$ Byla to tudíž i jakási performance. Obě důležitá díla už vznikla v New Yorku, kde si Rauschenberg pořídil ateliér, poté, co se vrátil z druhého pobytu na BMC a společného studijního výjezdu s malířem Cy Twomblym do Španělska, Itálie a Maroka (1952-53). Středomořský plenér ho paradoxně nemotivoval k malířským experimentům se světlem a barvou; ze své druhé cesty do Evropy vytěžil sérii krabicových asambláží (scatole personali) a závěsných „osobních fetišů (feticci personali). Utvrdil se v nich v polysémické účinnosti readymade reprezentace a zároveň ověřil správnost nastoupené cesty ke gestickému chápání materie. Rovnováha a napětí mezi oběma vibrujícími polaritami - mezi významem konceptu a výrazem materiálu - sehrály důležitou roli v Rauschenbergově poetice a estetice bez ohledu na zvolená média a žánry.

K intermediím dospěl Robert Rauschenberg paralelně dvěma cestami, jež se v 60. letech střetly v sérii instalací a performancí. Jednu dláždila vůle proniknout dovnitř malby a zároveň ji otevřít do časoprostoru a interakcí se světlem. Na druhou ho navedli Cage s Cunninghamem, když ho přemluvili, poté, co pro ně navrhl některé scénografie a kostýmy, aby v jejich tanečním souboru nahradil odcházejícího světelného technika. Opovážlivý výtvarník, ačkoli o světelném designu nevěděl zhola nic, nabídku přijal a brzy pochopil, že osvětlení je pro scénickou produkci stejně důležité jako choreografie, hudba, kulisy a kostýmy. V tom samém čase začal Rauschenberg spolupracovat s tanečníky a choreografy (Steve Paxton, Fred Herko, Trisha Brownová, Yvonne Reinerová, Elaine Summersová, aj.), kteří později vytvořili Judson Dance Theater, podle stejnojmenného kostela v Greenwich Village, kde zkoušeli a vystupovali. Kromě práce pro tanečníky

1 Rauschenberg uvádí, že de Kooning pro jeho projekt záměrně vybral takovou kresbu, o níž si myslel, že ji nebude snadné vygumovat, což se následně potvrdilo; Rauschenberg ji gumoval celý měsíc, než byl spokojen $\mathrm{s}$ výsledkem.

2 Cage řídil to samé auto, v němž předtím přivezl Rauschenberga na Black Mountain College, kde maliř pořídil jeho fotografii za volantem. Slavný snímek byl též zařazen na londýnsko-newyorskou výstavu. 
nadále posouval malbu k objektovosti a procesuálnosti, až mu obě oblasti jaksi přirozeně splynuly v autorských scénických intermediích.

\section{Kombinované malby}

V první polovině 50. let vytvořil Rauschenberg několik maleb, v nichž využil výrazovou sílu pastózní červeně, nahrubo aplikované přes vzorovanou textilii nebo novinový papír tak, aby vynikla strukturní rozmanitost nanesených a asamblovaných vrstev, díky čemuž stvořil jakési asémantické palimpsesty bez minulosti. Zcela spontánně se v nich vyrovnával s intelektuálními podněty abstraktního expresionizmu, jenž ho silně zasáhl. Do posledních děl tzv. „červeného“ období (1953-54) malíŕ začleňoval rozličné nalezené předměty, resp. fragmenty (zrcadélka, žárovky, apod.), které představují plynulý přechod ke kombinovaným malbám, tzv. combines, jež zplodila vášnivá fúze malby, skulptury a přivlastněných objektů, a jež ho nejvíce proslavily jako malíře. Touha přepojit umělecké médium s mimouměleckou realitou významně poznačila Rauschenbergův způsob malování. Po radikálních experimentech s imanentními aspekty obrazu - podkladem, barvou a rámem - ho začalo zajímat, jak se „nevinná“ barevná plocha plátna „vypořádá“ s brutálními intervencemi z vnějšího světa civilizace a masové kultury, to znamená už nejenom rám, ale i rámec. Výsledkem tohoto zájmu byly právě combines. A jelikož na prvých z nich dominovala červená, rozdíl mezi dvěma polohami, resp. obdobími, v jeho rychle se vyvíjející tvorbě je prakticky neodlišitelný. Skvělými př́iklady můžou být díla Charlene (1954) a Minutiae (Maličkosti;1954).

Podobně jako Cage, který vpustil do ř́iše tónů ty nejobyčejnější zvuky, i Rauschenbergovi stál jakýkoli běžný předmět či materiál za to, aby z něj udělal experimentální nebo referenční nástroj díla, komunikujícího současně s imanentním médiem i vnější skutečností, uměleckou i mimouměleckou. Zkušenost získanou z asamblování combines využil též ve scénografii (spolupracoval tehdy s tanečním souborem Mercea Cunninghama), a tak se jeho „obrazosochy“ posloupně měnily na instalace, stávaly se prostorovějšími, protože si mohl dovolit vkládat do nich větší objekty či přístroje (deštníky, rádia, budíky, ventilátory), i efemérnějšími, když některé vytvářel in situ z nalezených předmětů přímo na scéně anebo na jedno „použití“. Materiálovou objektovost malby spojil s procesuálností, konkrétnost formy se rozplynula v abstraktní časoprostorové představě. Je to zřejmé i z pozdějších poloh, když v 70. letech, po desetiletí experimentů s novými médii, redukoval výchozí materiál pro svoje asambláže na recyklovaný karton či textilii, a když v 80. letech, poté, co se znovu vrátil ke scénografii (spolupráce s Trishou Brownovou), začal použivat jako podklad pro projekce, fotografie a sítotisky kovové plochy, experimentujíce už i s chemickými vlastnostmi nátěrů a galvanizačních technik.

$\mathrm{Z}$ hlediska integrace zvuku do vizuální reprezentace byla důležitým mezníkem kombinovaná malba Broadcast (Rozhlasové vysiláni; 1959). Rauschenberg do ní kromě tiskovin a plastového objektu (hřebene) začlenil též tři funkční rádia, aniž by byla z pohledu diváka viditelná. Zdroje zvuku, důmyslně ukryté pod povrchem plátna, jsou významově 
rovnocenné s výtvarnými prostředky, jelikož umělec odmítal média a materiály, s nimiž pracoval, hierarchizovat podle důležitosti. Použil cokoli, co se mu zrovna hodilo a co měl po ruce, bez ohledu na umělecký nebo neumělecký původ. Byly to dary civilizace, jichž se zmocňoval s přirozenou nonšalancí, nezatížen stále složitějšími definicemi, kategoriemi či taxonomiemi světa umění. $\mathrm{V}$ této demokracii medií a materiálů přestávala být jasná i samotná umělcova profese, jelikož se vzdaloval nejen reprezentačním konvencím, ale též druhovým a žánrovým vymezením. Dospěl do mezistavu a meziprostoru, kde a odkud byly najednou směry, vzdálenosti či rychlosti zcela nepodstatné. V rozhovoru s Richardem Kostelanetzem na otázku, co podle něj charakterizuje divadlo smíšených prostředků, Rauschenberg odpověděl: „Absence hierarchie - skutečnost, že v jediném kusu Yvonne Rainerové můžete slyšet Rachmaninova i tyče hozené z balkónu, aniž by tyto dvě věci navzájem nĕjak souvisely. $V$ mých kusech, např̌klad, neni nic ničemu podřizené. Abych udržel plynulost díla, spoléhám na každý jeho prvek."3 V Broadcast je tudíž zvuk, vycházející přes plátno z rádií naladěných na různé frekvence a nastavených na rozdílné hlasitosti, stejně důležitý jako malba, či do ní vlepené novinové výstř̌ižky. Malba je dokončena, zvuk ne; navíc ho lze ovlivnit díky vystupujícím otočným knoflíkům radiopřijímače. Spolu se zvukem vstoupil do díla čas, stal se jeho součástí, vektorem animujícím jeho prostorové koordináty. Obrazu lze najednou naslouchat a, díky proklamované absenci hierarchie, dokonce ignorovat jeho vizuální zjev. První si toho všiml John Cage, nakonec byl u toho, když se Rauschenbergovy experimenty s malbou rodily: „Když nyni Rauschenberg vytvořil malbu, $v$ niž jsou rádia, znamená to, že i bez nich musím při díváni poslouchat, všechno najednou, abych se nenechal prejet? [...] V kombinovaném obrazu neni více námètu než ve stránce $z$ novin. Vše, co tam je, je námètem. Tato situace zahrnuje mnohost. [...] (A jsou-li tři rádia $v$ rádiovém kombinovaném obraze zapnutá, které poskytuje námèt?) Řekneme, že tam bylo poselstvi. Jak by bylo príiato? A co kdyby nebylo? Stále a stále dokola si nejsem schopen zapamatovat Rauschenbergovy malby. Stále se ptám. ,Zmènil jsi to?‘ A pak si všimnu, že se obraz měni, zatímco se dívám." A Anebo: zatímco poslouchám.

\section{Instalace}

Cage trefil hřebík na hlavičku. Rauschenberg ze synestetického „chaosu“ vytvořil nový percepčně-recepční řád, kde je stabilní pouze nestabilita, a spolu s ním stvořil i novou žánrovou estetiku. Od kombinované malby s rádii byl už jenom krůček k prostorovým instalacím, v nichž dovedl princip mimésis a uměleckou distanci reality vůbec až k bezprostřední imanenci. V působivé asambláži Oracle (Orákulum; 1962-65) je pět autonomních readymade bloků na kolečkách, sestavených výlučně z nalezených, většinou plechových objektů (komínová roura na nápravě od povozu, automobilové dveře a slisovaný kovový blok připevněné $\mathrm{k}$ podstavci od psacího stroje, roura od ventilace, vodovodní potrubí

3 KOSTELANETZ, Richard. The Theatre of Mixed Means. Londýn: Pitman Publishing, 1970, s. 86.

4 CAGE, John. Silence. Praha: Tranzit, 2010, s. 101-102. 


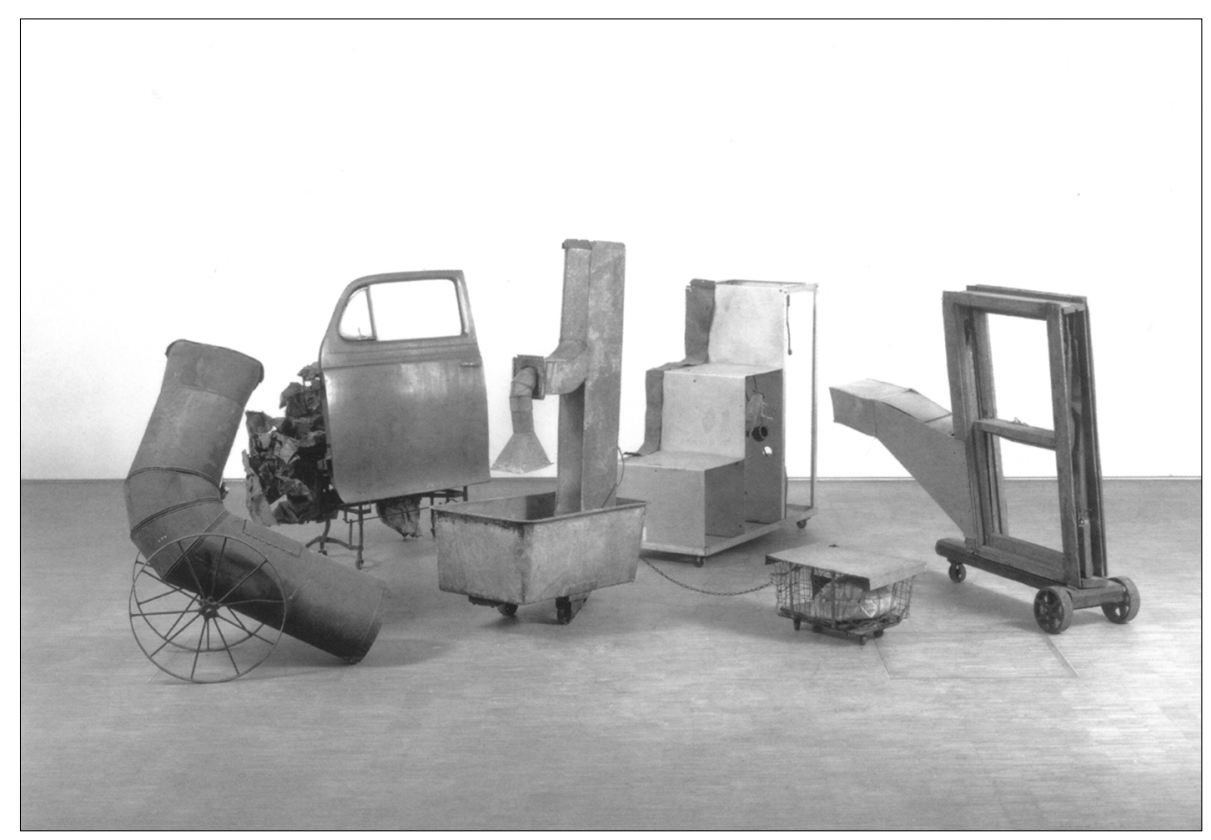

Obr. 1 Robert Rauschenberg: Oracle (Orákulum), 1962-65, Musée National d'Art Moderne, Centre Pompidou, Paříž; dar Sao a Pierra Schlumbergerových; Foto: (c Centre Pompidou.

ve vaně na míchání betonu, přepravní vozík s kovovým krytem, schodová konstrukce, dřevěný okenní rám na kolečkách), asociačně propojeno pouze skrze vizuální (nevýrazně šedou barvu všech bloků) a akustické (zvuky, vycházející z tajemných zdrojů) informace. Bezradný divák zírá na skládku starého harampádí a slyší zvuky, jež vůbec nekorespondují s tím, co vidí - rozhlasové vysílání, vycházející z pěti rádiových reproduktorů, ukrytých v jednotlivých částech instalace, a neviditelnou vodu cirkulující přes vodovodní potrubí z vany míchačky a zpátky do ní. Co má očekávat od takovéto audiovizuální reprezentace? Jakou interpretační strategií uchopit její poselství, jestli tam vůbec nějaké poselství je, jak obezřetně zapochyboval Cage? Rauschenberg divákům nastražil záludnou past, když mezi médiem a poselstvím ustanovil nehierarchický, vzájemně ambivalentní vztah. Jeho Orákulum je samozřejmě o něčem, dokonce je o americkém světě 60. let 20. století. Je však o něm jiným způsobem, než na jaký byl svět umění v jeho době zvyklý. $\mathrm{V}$ historickém kontextu se pro smysluplnou interpretaci Orákula nabízejí třeba některé teze McLuhanovy estetiky nových médií, která se zrovna v té době rodila. Rauschenberg s oblibou říkával, že své umění dělá „z darů ulice“. Ulice mladých amerických velkoměst nabízely v 60. letech minulého století kromě technického odpadu ještě toxičtější mediální odpad. Ale rozvážný umělec nepodlehl vlivu prvoplánové kritiky konzumu a mediálního šílenství, s jakou přišli pop artisté, a zůstal pevně ponořen do imanentních vlastností materiálu, jež mu z reprezentačního hlediska učaroval mnohem více. Docílil tak obdivuhodného esteticko-poetického kompromisu mezi bezbřehostí mimoumělecké reality a časoprostorovými omezeními tradičních výtvarnických médií. Propojil je nejnovější 
technologií, v čem mu pomáhal inženýr Billy Klüver, specialista v oblasti laserových technologií a optiky z Bellových laboratoří, se kterým později iniciovali projekt E.A.T. (Experiments in Art and Technology).

Díky kolečkám, na nichž jsou všechny bloky instalovány, a zvukům vody a rádií Orákulum sugeruje nestabilitu, pomíjivost, možnost pohybu a navíc je i interaktivní. Nejenže umožňuje rekonfiguraci jednotlivých bloků, diváci si i mohou sami na rádiích, umístěných zezadu schodové konstrukce, nastavit hlasitost a rychlost přepínání rozhlasových stanic. Klüver nazval dílo „animovanou městskou krajinou“ (animated cityspace), což je velice příznačné označení. Rádiové vysílání se Rauschenbergovi zdálo nejvhodnější reprezentací nahodile spřádaných každodenností. Podobně jako před ním John Cage v kompozicích Imaginary Landscape No. 4 (1951), Radio Music (1956), Music Walk (1958) a Water Walk (1959), i on použil rádio jako médium zprostředkující př́ijemcům (u Cagea i interpretům) nepředvídatelné zážitky; právě díky rádiím se poselství Broadcastu a Orákula nanovo aktualizují, jelikož vysílají vždy nové a nové zprávy. Rádio, orákulum moderního věku, promlouvá k lidem budoucnosti skrze asambláž starých objektů, jejichž vzhled a funkce jsou záměrně dezaktualizované. Zůstává pouze nejapný zvuk, technologicky transformován na informační šum. Zvuk, bez něhož „se nestane nic podstatného,“ jelikož svět „neni čitelný, nýbrž slyšitelný. “5

Rauschenberg pracoval se zvuky i v instalaci Mud Muse (Bláto múzou; 1968-71), v tomto případě je však využil jako spouštěče bublání a vytryskování bahnité směsi bentonitového jílu (používá se při ropných vrtech), kterou napustil kovový bazén se skleněnými mantinely. Indiferentně vypadající hmota v bazénu bublá v závislosti na výškách frekvencí zvuků bublání, přehrávaných z magnetofonového pásu (nahrávky pořídil umělec v roce 1969), a reaguje i na zvuky bezprostředního okolí (galerie, diváci). Z neomezené nabídky zvuků, které měl umělec k dispozici, včetně hudebních, si pro aktivaci instalace vybral ty nejzáludnější - zvuky samotného bublání, jehož chtěl následně docílit. Tři roky mu trvalo, než ve spolupráci s týmem pěti inženýrů z losangeleské vývojářské společnosti Teledyne stvořil toto prazvláštní simulakrum, kde divák vnímá bublání způsobované zvuky předešlého bublání. Díky důmyslnému, technologicky náročnému zařízení docílil toho, že zvuky generovaly a ovládaly pohyby. Výsledný procesuální efekt díla umožnily vzdušné pumpičky umístněné na dně bazénu, které díky zvukovým senzorům uvolňovaly rozdílná množství vzduchu v závislosti na frekvenci právě přehrávaného zvuku. Bylo to na svou dobu neobvyklé technické řešení, předznamenávající interaktivní umění digitálního věku.

\section{Performance}

Zrovnoprávnění výtvarnických materiálů s přisvojenými objekty a zvuky v kombinovaných malbách a instalacích ještě více podnítilo Rauschenbergovu touhu ovládnout prostor a kromě zraku stimulovat i další smysly diváků. Zkušenosti, získané spoluprací

5 ATTALI, Jacques. Noise: The Political Economy of Music. Minneapolis - London: University of Minnesota Press, 1985, s. 3. 
s Tanečním souborem Mercea Cunninghama, ho přivedly k vlastním scénickým intermediím, kde spojil novou výtvarnou předmětnost s pohybem a invenčními technologickými experimenty.

Prvním byl Pelican (Pelikán; 1963). Rauschenberg se v něm spolu s dalšími umělci (Per Olof Ultvedt, Alex Hay, Carolyn Brownová) pohybovali na kolečkových bruslích s vlajícími padáky, jež ovlivňovaly rychlost jejich pohybů, a zároveň sloužili jako dynamické scénografické rekvizity. Volba kolečkových bruslí měla své důvody: na jedné straně to byl „dar ulice“, materiál odkazující na mimouměleckou skutečnost i procesuální arbitrárnost uměleckého média; na straně druhé měly brusle zabránit účinkujícím v naučených tanečních pohybech, jež byly pro nehierarchickou reprezentaci nežádoucí. „Protože jsem nevěděl moc o tom, jak se dělá tanec,“ řekl umělec, „použil jsem kolečkové brusle jako prostředek osvobozeni od jakýchkoli připadných zábran. Už to vás omezuje - tlači vás to do jisté oblasti, kterou se musite zabývat. Využil jsem omezeni materiálu jako svobodu a to nakonec určilo formu. $V$ kusu jsem angažoval tanečniky a k mému překvapeni jsem zjistil, že tanečníci, kteři jako děti bruslili, někteři dokonce velmi dobře, dnes už bruslit neumi, protože jim v tom zabraňuji jejich tanečni návyky. Byli strnuli a nemotorni. Aby se to znova naučili, museli se něčeho vzdát. Vite, tanečníci při tanci vedou dialog mezi sebou a podlahou, a když jsem mezi ně a podlahu vložil kolečka, už neslyšeli podlahu a jejich svaly ztratily orientaci. [...] Šlo mi jenom o formu pohyblivosti. V představeni byla i dalši kola. Ale jelikož jsem ten kus nazval tancem a nechtěl jsem, aby to bylo pouze brusleni, musel jsem jaksi přidat dalši složky, a tudiž Carolyn Brownová, která

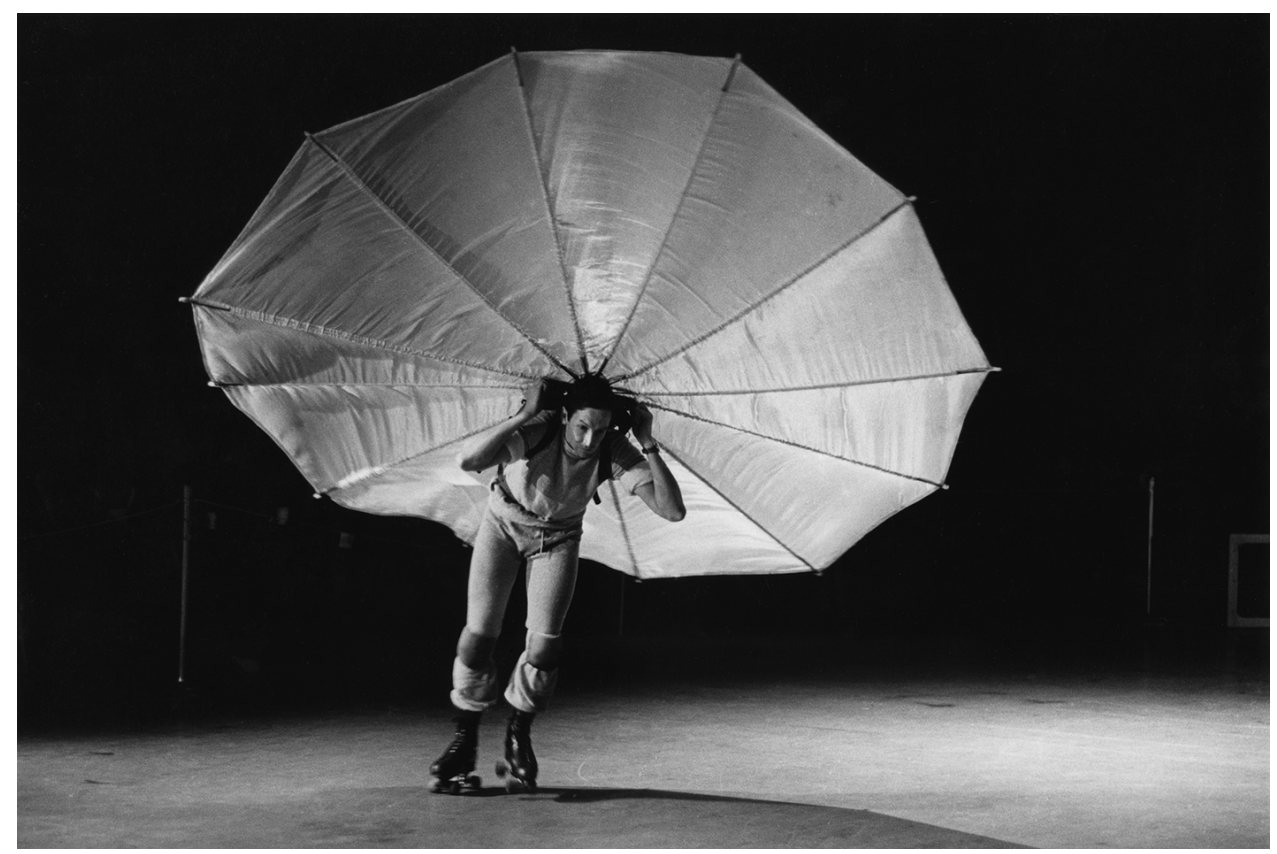

Obr. 2 Peter Moore: fotografie Roberta Rauschenberga performujícího v kusu Pelican (Pelikán) v newyorském televizním studiu CBS; 1965. 
nebyla na bruslich, tancovala na špičkách, což byl vlastně doplňkový způsob pohybu. "6 Živá těla performerů splynula s neživými prvky scény a vytvořila tak organický časoprostorový celek. Tomuto způsobu reprezentace zůstal věrný i v dalších choreografických performancích - Spring Training (Trénování pružnosti; 1965), Map Room I, Map Room II (Plán prostoru I a II; 1965) a Linoleum (1966), kde pro integraci fyzických pohybů (civilních, pracovních, sportovních) do tance využil různé technologické výdobytky (světelné efekty, filmové projekce, atd.).

Snaha začlenit do uměleckých forem mimouměleckou realitu a moderní technologie vyvrcholila v Rauschenbergově tvorbě v roce 1966 platformou E.A.T. Inicioval ji spolu s performerem a experimentálním divadelníkem Robertem Whitmanem a elektroinženýry Bellových laboratoří Billy Klüverem a Fredem Waldhauerem. Výstupem jejich společného snažení byl cyklus akcí v historické budově bývalé zbrojnice na Manhattanu (69th Regiment Armory), nazvaný 9 Evenings: Theatre Eं Engineering (9 večerů: Divadlo a inženýrstvi). Na ambiciozním projektu spolupracovalo 10 umělců (kromě Rauschenberga a Whitmana ještě John Cage, David Tudor, Steve Paxton, Lucinda Childsová, Alex Hay, Deborah Hayová, Yvonne Rainerová a Öyvind Fahlström), 30 inženýrů a vzešlo z něj 10 filmových dokumentů. Od projektu se podle všeho očekávala dlouhodobá systémová mezioborová spolupráce, měl však spíše charakter novodobé alchymické laboratoře s jednorázovými výsledky. Rauschenberg z něj vytěžil interaktivní performanci Open Score (Otevřrená partitura), v níž se výtvarník Frank Stella, amatérský tenista, utkal v zápasu s profesionální hráčkou Mimi Kanarekovou. Inženýři vmontovali do rukojetí jejich raket FM krystalky a kontaktní mikrofony a kolem hlav raket obtočili antény. Vibrace výpletu, způsobované údery míčku, se takto přenášely do rozhlasového přijímače, zesilovaly a následně vysílaly přes soustavu reproduktorů. Zesílené zvuky úderů posloupně vypínaly světla, až se celá hala zbrojnice ponořila do naprosté tmy a zápas zdánlivě skončil. Na improvizovaný dvorec však najednou vtrhnou stovky lidí, zvuky úderů se ozývají dále a členové davu se postupně nahlas představují, zviditelnění obecenstvu díky infračervené projekci. Ze tmy se vynoří skrčená postava dívky (Simone Fortiová) a celá zahalená do bílé plachty zpívá toskánskou lidovou píseň. Nakonec se objeví i sám autor a přenášíji v náručí na různá místa zbrojnice, až dokud dívka nepřestane zpívat. Rauschenberg mezi zvukem a tichem, světlem a tmou, viditelností a neviditelností rozehrál improvizované pohybové akce a stvořil dynamické intermedium, manifestující všechny aspekty rodící se transžánrové kreativity - performativnost, otevřenost, participaci, interaktivitu a interdisciplinaritu. Naznačil též filozofické záludnosti autoreference a antiesencialismu, jakožto principů, ohlašujících éru nové, zatím ještě nedigitální reprezentace.

6 KOSTELANETZ, Richard. The Theatre of Mixed Means. London: Pitman Publishing, 1970, s. 82-83. 


\section{Bibliography}

ATTALI, Jacques. Noise: The Political Economy of Music. Minneapolis-London: University of Minnesota Press, 1985. Anglický překlad: Brian Massumi.

CAGE, John. Silence. Praha: Tranzit, 2010. Český překlad: Jaroslav Štastný, Radoslav Tejkal, Martin Kratochvíl.

DICKERMAN, Leah - BORCHARDT-HUME, Achim. Robert Rauschenberg. Londýn - New York: Tate Publishing / The Museum of Modern Art, 2016.

KOSTELANETZ, Richard. The Theatre of Mixed Means. London: Pitman Publishing, 1970.

PAGNUTTI, Alana. Reception: The Radio-Works of Robert Rauschenberg and John Cage. London: Smith+Brown, 2017.

RAUSCHENBERG, Robert. Open Score. New York: E.A.T \& Artpix, 2007. 